\title{
Theories of disability in health practice and research
}

\author{
MICHAEL OLIVER
}

\section{University of Greenwich, Eltham, London SE9 2UG, UK}

All health care and research are influenced by theories. This paper considers the influence of implicit and explicit theories ${ }^{1}$ on interventions and research on disabled people. Another important influence is the experience of disabled people, and their increasing insistence that their voices be heard at all stages of research about their lives. ${ }^{2}$

\section{The experience of disability}

Over the past 20 years, writings by disabled people have transformed our understanding of the real nature of disability. They move beyond the personal limitations that impaired individuals may face, to social restrictions imposed by an unthinking society. Disability is understood as a social and political issue rather than a medical one, and this leads to critical questioning of medical interventions: attempts to cure impairments or to restore 'normal' bodily functioning. Instead, social and political solutions are sought, to challenge disabling discrimination.

\section{Summary points}

The health care that disabled people receive is influenced by theories

Positivist theory remains the dominant influence on health care given to disabled people

Other theories are beginning to have a significant influence

The rise of these theories is posing important questions for health care and research

This radically different view is called the social model of disability, or social oppression theory. ${ }^{3}$ While respecting the value of scientifically based medical research, this approach calls for more research based on social theories of disability if research is to improve the quality of disabled people's lives. Definitions are central to understanding theories of impairment and disability. ${ }^{4}$ In 1986 Disabled Peoples International made a clear distinction: impairment is the functional limitation within the individual caused by physical, mental or sensory impairment; disability is the loss or limitation of opportunities to take part in the

This article is reproduced with permission from the British Medical Journal, 1998; 317: 1446-1449. 
normal life of the community on an equal level with others because of physical and social barriers.

This schema accepts that some illnesses have disabling consequences and disabled people at times are ill; it may be entirely appropriate for doctors to treat illnesses of all kinds, such as bronchitis or ulcers. Yet it questions why, for example, doctors should decide about access to welfare services such as education or disability living allowance. Theories of impairment, disability, and illness influence which aspects of disabled people's lives require health treatment, or policy developments, or political action, as sometimes radical alternatives (see box). ${ }^{5}$

\section{Interventions to normalize impairments}

$\begin{array}{ll}\begin{array}{l}\text { Impairment } \\ \text { Deafness }\end{array} & \begin{array}{l}\text { Intervention } \\ \text { Cochlear implants }\end{array} \\ \begin{array}{l}\text { Cerebral palsy } \\ \text { Achondroplasia }\end{array} & \begin{array}{l}\text { Conductive education } \\ \text { Limb lengthening }\end{array} \\ \begin{array}{l}\text { Down's syndrome } \\ \text { Congenital }\end{array} & \text { Cosmetic surgery } \\ \text { Genditions } & \text { Gereening }\end{array}$

Alternatives
Sign language teaching in
schools
Barrier removal
Barrier removal, awareness
raising
Awareness raising
Legislation for equal
opportunities

\section{Positivism and disability research}

Health research about impairment and disability is dominated by positivist theories. It focuses on searches for cures, means of reducing impairments, or assessments of clinical interventions and uses methods such as controlled trials, random statistical samples, and structured questionnaires. Even when researching disability (in the sense given above), positivist research tends to use the World Health Organisation's classification, ${ }^{6}$ now being revised at the insistence of disabled people, ${ }^{7}$ which is difficult if not impossible to apply in research terms and yields few useful data.

Disabled people are beginning to influence scientific research. ${ }^{8}$ This influence poses difficulties for positivist research in questioning one of its bedrocks: the notion of objectivity. Although positivist researchers accept that subjectivity can be studied objectively, they resist involving subjects for fear of bias. However, scientific researchers often use the words 'suffering' and 'victim' as if they are accurate descriptions and not untested, biased assumptions which many disabled people do not experience. In contrast, social constructionism sees experience and subjectivity as central to the research process, and critical theory sees disabling barriers as a key research issue. Though these theories pose intellectual challenges, almost all funding goes to positivist research.

The influence of implicit and explicit positivism on the Department of Health which, it seems, has discovered the 'user' is shown in a recent report: 'The NHS is attaching increasing importance to seeking out and acting upon the views of its users on the coverage and delivery of the services it provides. ${ }^{9}$ The programme has spent $£ 3.9$ million on 30 projects; all are 
located in universities or the health service. Despite consumer views being the second named priority for selecting research proposals, disabled people have not been involved. None of their organizations have received funding, and no projects could be said to be based on the social model of disability - they are all based on positivist theories. ${ }^{10}$

\section{Social approaches within positivism}

Positivist social medicine recognizes the social context to impairment as well as disability, and it examines environments as well as individuals. Hence public health measures concerned with sanitation, poverty, health education, and the like have proved extremely effective in preventing rather than curing a range of impairments such as tuberculosis, polio, rickets, and river blindness.

Prevention of impairments is complicated, however, by prenatal screening to prevent conditions such as Down's syndrome, cystic fibrosis, or Huntington's chorea, and by research into genetic engineering. Leaving aside the efficacy of such interventions, they pose profound ethical, social, and cultural issues for us all. 'Life and death decisions are vested in the hands of people who have very little understanding of the reality of disabled people's lives. ${ }^{11}$ With the lack of systematic evidence, why should doctors assume, for example, that life with Down's syndrome is not worth living?

Social approaches to disability ${ }^{12}$ within positivism classify and count disabled people. Although some support this work, ${ }^{13}$ others question the accuracy of the data ${ }^{14}$ and say that they yield few significant changes for disabled people. ${ }^{8}$

Recent research, attempting to combine theories, and scientific measures of the extent of disabling barriers with disabled people's own experiences of the extent and nature of those barriers, involves disabled people in designing, collecting and analysing the data. ${ }^{15}$ Its success remains to be seen.

\section{Functionalist theory and disability}

Influential functionalists emphasize medicine's role to cure and to maintain the 'normal' functioning of individuals and of society. In this model, the 'sick role' involves being compliant and wanting to get well. ${ }^{16}$ This can make people with incurable conditions, including disabled people who are classified as sick, seem to be deviant. The link between disability and social deviance that functionalists make influences health care and research and supports the continued dominance of professionally controlled health and welfare services for disabled people. ${ }^{17}$ Thus, under current welfare arrangements, more than $70 \%$ of spending goes on the salaries of professionals working with disabled people. Only recently has this been reduced through the funding of independent living schemes controlled by disabled people. A variant of functionalism, normalization theory, underlies some programmes that claim to enable devalued people to lead culturally valued lives. An example of this controversial approach is cosmetic surgery for people with Down's syndrome.

Functionalism confuses impairment and disability with the sick role. By failing to recognize that disabled people do not necessarily have 'something wrong with them' it simply reproduces discriminatory norms with values-instead of addressing the cultural and economic forces that precipitate them. The crucial problem is that disabled people, regardless 
of the type or severity of their impairment, are not a homogeneous group that can be accommodated easily within a society that takes little account of their individual or collective needs. As with the whole population, disabled people differ widely in terms of ethnic background, sexual orientation, age, abilities, religious beliefs, wealth, access to work, and so on. Clearly, their situation cannot be understood or, indeed, transformed by any policy based on narrow theories of conventional normality or uniformity.

\section{Social constructionism}

This theoretical approach is centrally concerned with meaning. It shows the crucial importance of learning from disabled people's experience to understand meanings of disability. For example, blindness differs according to the economic and cultural contexts. A classic study showed that in the United States blindness was experienced as a loss requiring counselling, in Sweden as a problem requiring support services, in Britain as a technical issue requiring aids and equipment, and in Italy as the need to seek consolation or even salvation through the Catholic church. ${ }^{19}$

Anthropologists and historians show how different societies produce certain types of disease, impairment, and disability. ${ }^{20}$ Disability can be produced by 'the disability business.' In modern America, industrialization, the subsequent growth of the human service sector, and the more recent politicization of 'disability rights' by the American disabled people's movement have transformed 'disability' and 'rehabilitation' into a multimillion dollar enterprise. Disability becomes a commodity and a source of income for doctors, lawyers, rehabilitation professionals, and disability activists.

These examples treat disability as a shared experience, in contrast with conventional individualistic interpretations. yet each fails to address key structural factors. Consequently, disabled people tend to be treated as an abstract, somehow distinct from the rest of the human race, and the crucial question of the causes of disability is fudged rather than clarified. For example, how is disability physically based but socially constructed by the disabling environment? ${ }^{20}$

\section{Postmodernism}

Postmodernism sees society in terms of fragmented and complex social structures in which social class has less importance, and other sources of social difference (including sex, ethnicity, sexuality, and disability) have more importance. Postmodernists call into question many of the certainties of earlier eras, creating multiple meanings for practically everything.

This theory has, as yet, had little impact on health research about disability. However, a study on concepts of a healthy body, so central to government health promotion, is beginning to show how these concepts can, in themselves, be disabling, unrealistic, and oppressive. 'Health promotion is working against popular culture, attempting to construct a view of health that is not privately held. ${ }^{21}$ In other words, to have an impairment is not necessarily unhealthy; disabled people are not actually ill, and confusion between impairment and illness fails to deal with the complex meanings in the postmodern world. 


\section{Critical theory}

Critical theory covers similar ground to the other theories discussed here, but sees disabled people's problems explicitly as the product of an unequal society. It ties the solutions to social action and change. Notions of disability as social oppression mean that prejudice and discrimination disable and restrict people's lives much more than impairments do. ${ }^{22}$ So, for example, the problem with public transport is not the inability of some people to walk but that buses are not designed to take wheelchairs. Such a problem can be 'cured' by spending money, not by surgical intervention, assistive computer technology, or rehabilitation.

Ideologies perpetuate practical barriers and exclusions. ${ }^{23}$ As long as disability is assumed to be an individual matter of personal tragedy or heroic triumph over difficulty, disabled people are excluded from society. Ordinary education, employment, buildings, public transport, and other things which most people can take for granted remain largely closed to disabled people, or at least they present obstacles which each person has to tackle individually. By emphasizing deficiency and dependency, doctors tend to reinforce these ideologies. $^{24}$

The impact of this critical theorizing on health care and research has tended to be indirect. It has raised political awareness, helped with the collective empowerment of disabled people ${ }^{25}$ and publicized disabled people's critical views on health care. It has criticized the medical control exerted over many disabled people's lives, such as repeated and unnecessary visits to clinics for impairments that do not change and are not illnesses in need of treatment. Finally, it suggests a more appropriate societal framework for providing health services for disabled people. ${ }^{26}$

\section{Conclusion}

Implicit and explicit social theorizing, coupled with disabled people's insistence that their voices be heard, have begun to change understandings of the nature of impairment and disability. The new understandings pose key questions for health care and research if they are going to provide an appropriate knowledge base for both medical and social progress:

- What is the proper balance for investment between research into bodily impairment and into social disability?

- Who should be setting the research agenda?

- Who should be in control of the research process?

- What are the most appropriate methods for undertaking disability research?

- How should disability research be disseminated and evaluated?

Such questions help us to identify both the common ground and fundamental differences between researches. ${ }^{27-29}$

\section{References}

1 Alderson P. The importance of theories in health care. BJM, 1998; 316: in press.

2 Barnes C, Mercer G, eds. Doing disability research. Leeds: Disability Press, 1997.

3 Oliver M. The social model in context. In: Understanding disability: from theory to practice. Basingstoke: Macmillan, 1996; 30-42. 
${ }^{4}$ Oliver M. Defining impairment and disability: issues at stake. In: Barnes C, Mercer G, eds. Exploring the divide: illness and disability. Leeds: Disability Press, 1996; 39-54.

5 Shakespeare T. Re-defining the disability problem. Critical Public Health, 1995; 6: 4-9.

6 Wood P. International classification of impairments, diseases and handicaps. Geneva: World Health Organisation, 1980.

7 Tennant A. Models of disability: a critical perspective. Disability and Rehabilitation, 1997; 19: 478-479.

${ }^{8}$ Oliver M. Changing the social relations of research production. Disability, Handicap and Society, 1977; 7: 101-115.

${ }^{9}$ Peckham M. Foreword. In: Consumers and research in the NHS. Leeds: Department of Health, 1995.

${ }^{10}$ Oliver M. Emancipatory research: realistic goal or impossible dream: In: Barnes C, Mercer G, eds. Doing disabled research. Leeds: Disability Press. 1997; 15-31.

${ }^{11}$ Begum N. Rock-a-bye baby, or the treatment might stop: a discussion of the selective treatment of disabled babies. Critical Public Health, 1995; 6: 30-7.

12 Martin J, Meltzer H, Elliot D. OPCS Surveys of disability in Great Britain: report I-the prevalence of disability among adults. London: HMSO, 1988.

13 Bury M. Defining and research disability: challenges and responses. In: Barnes C, Mercer G, eds. Exploring the divide: illness and disability. Leeds: Disability Press, 1996; 17-38.

14 Abberley P. Disabled by numbers. In: Levitas R, Guy W, eds. Interpreting official statistics. London: Routledge, 1996; 161-184.

15 Zarb G. Researching disabling barriers. In: Barnes C, Mercer G, eds. Doing disability research. Leeds: Disability Press. 19977; 49-66.

16 Parsons T. The social system. Glencoe, IL: Free Press, 1951.

17 Oliver M. A sociology of disability or a disablist sociology. In: Barton I, ed. Disability and society: emerging issues and insights. London: Longman, 1996; 18-42.

18 Chappell A. Towards a sociological critique of the normalization principle. Disability, Handicap and Society, 1992; 7: 1.

19 Scott RA. The making of blind men. London: Sage, 1969.

20 Albrecht G. The disability business. London: Sage, 1992.

${ }^{21}$ Watson N. Health promotion and physically disabled people: implications of the national health policy. Critical Public Health, 1995; 6: 38-43.

22 Sutherland A. Disabled we stand. London: Souvenir Press, 1981.

23 Abberley P. The concept of oppression and the development of a social theory of disability. Disability, Handicap and Society, 1987; 2: 5-21.

${ }^{24}$ Oliver M. The politics of disablement. Basingstoke: Macmillan, 1990.

${ }^{25}$ Campbell J, Oliver M. Disability politics: understanding our past, changing our future. London: Routledge, 1996.

${ }^{26}$ Barnes C. Disabled people in Britain and discrimination: a case for anti-discrimination legislation. London: Hurst, 1991.

27 Barnes C. Disability and the myth of the independent researcher. Disability and Society, 1996; 11: 107-110.

${ }^{28}$ Bury M. Disability and the myth of the independent researcher: a reply. Disability and Society, 1996; 11: 111-113.

${ }^{29}$ Shakespeare T. Rules of engagement: doing disability research. Disability and Society, 1996; 11: 114-119. 